\title{
'You have to make up your own story here': Identities in cyberspace from Twitter to Second Life ${ }^{1}$
}

Theo Meder, Meertens Instituut, Amsterdam, The Netherlands

\section{Introduction}

Not so long ago, there were people who thought that the Internet, social media and online games had very little to do with real life. For instance, you have family, friends, colleagues, work, sports, holidays and celebrations in real life, and the Internet was merely an imaginary playground for nerds and freaks, wanting to escape the real world.

I dare say the world has changed since the beginning of this year 2011, when two large facts became clear:

1. Daily politics turns out to be a façade. The hidden truth was exposed on the Internet by Wikileaks. By publishing tens of thousands of secret diplomatic documents on the web, Julian Assange proved that there is a difference between what politicians secretly think and do in real life, and what they tell the public in front of a camera or microphone. The documents in cyberspace gave us a more truthful account of real-life events than our politicians did in reality.

2. Social media can start revolutions. Where 20th-century invasions and warfare failed to bring democracy and a much-hoped-for domino effect in the region (Afghanistan, Iraq), 21st-century social media triggered Arab revolutions against poverty, unemployment, abuse of power, suppression and corruption in countries like Tunisia, Egypt, Libya and Syria. Social media and freedom of information did cause the domino effect that bombs and tanks could not.

The Internet is faster than any other medium, it can inform and educate the masses for free, and it is able to unite people. In the years to come, computers and the Internet will become yet more integrated in our daily lives. We used to have one computer per household, but in the Western world we are already approaching a rate of one computer per room. Other media, such as newspapers, books, radio, telephone and television, will not disappear, although they are slowly but surely being assimilated by such things as our desktop computers, laptops, notebooks, tablets, smart phones and e-readers.

\footnotetext{
${ }^{1}$ This is a reworked version of the paper I presented at the $10^{\text {th }}$ international SIEF congress in Lisbon, Portugal, 18 April 2011.
} 


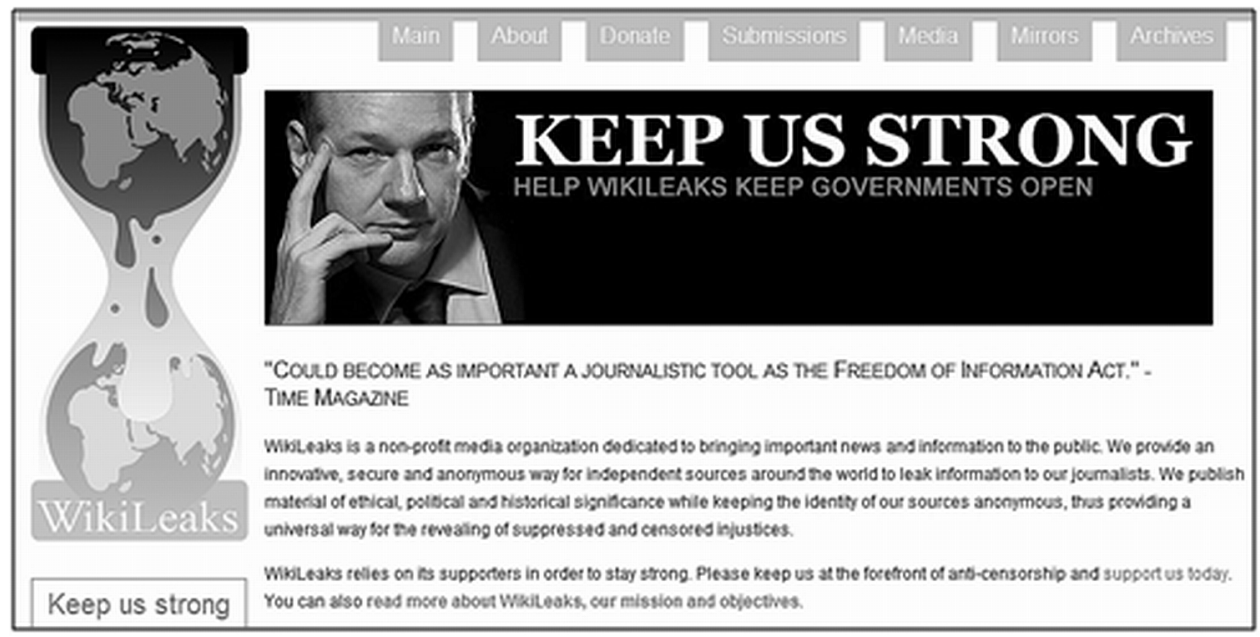

WikiLeaks

Mankind is a homo narrans and a homo ludens - we love fiction and game-play ${ }^{2}$, probably more than any other species on Earth. Our means to fantasize and play have become extensive. Again the computer enables us to visualize fantasy worlds, experience adventures and participate in stories like never before ${ }^{3}-$ the game industry already earns more money a year than the movie industry does. We have hardly reached the limits of our possibilities. If researcher Janet Murray is right, the future of narrative in cyberspace will be the holodeck, similar to what we have seen in the Star Trek series. ${ }^{4}$ We will no longer be reading a story from a monitor, or playing a game by gazing at a screen, we will literally be sucked into the action. Reading a novel or playing a game will become a 3D holographic experience: we will be able to walk around in the scenery and we will participate actively in the plot.

However, that is science fiction for now. What we can do is experiencing all kinds of fantasies and stories in virtual worlds and games. Unlike with books, television and movies, all the experiences are more or less interactive: as a director

\footnotetext{
${ }^{2}$ See Tavinor 2009, pp. 19-33, on the aspects of (game) play, narrative and (interactive) fiction.

${ }^{3}$ I am focusing here on computer games with some kind of (possible) narrative structure (cf. Walter 2002), preferably some kind of adventure or role-play, not on games of skill like Pong, PacMan or Tetris.

${ }^{4}$ Murray 1998; Castronova 2008, pp. 3-5, compares Second Life and other virtual entertainment to holodeck experiences and calls it the "fun revolution" (p. 7). The science fiction movie Surrogates, by Jonathan Mostow (2009) and starring Bruce Willis, describes a slightly different scenario: while people stay indoors connected to their computers, their non-virtual avatars go out into the real world to work and have fun. The same idea of a reallife replacement was worked out in Avatar by James Cameron (2009).
} 
or an actor, you can decide what happens next. At present, for most games, this is not entirely true, since the game makers create one or more plot outlines that you more or less have to follow to reach the end of the narrative. If you fail to do so, you get stuck. ${ }^{5}$

In the past, computer game play was a solitary activity, but today the Internet enables online gaming with one, a few or many players from all over the world. There is even a name for the latter activity: MMORPG, which means Massively Multiplayer Online Role-Playing Game (Tavinor 2009, p. 203). Famous examples are World of Warcraft and EvE Online. There are a few online games that bring people together in which the narrative is (almost) completely free, as in social games like The Sims or Second Life. One could even argue whether or not we are dealing with games here (Timroff 2007, p. X). Is Second Life a virtual 3D world in which avatars act out their stories, or is it merely a chat program in a $3 \mathrm{D}$ environment (Castronova 2008, p. 43)? Anyway, the advantage of online games like Second Life is that people are (almost) completely free to create their own avatar, build their own world, make up their own story and perform their own narrative.

Next, I would like to examine some possibilities that people have chosen to represent themselves online, and how a chosen identity can determine certain behaviour or narratives. I still stand at the beginning of my survey, so the following is a first exploration of the field rather than the result of extensive research.

\section{Twitter and Facebook}

At one end of the spectrum of digital self-representation there are social media like Twitter and Facebook, where in many cases the virtual personal representation closely resembles the real person's life. Speaking for myself, the person in my Facebook and Twitter account is basically me, or at least contains aspects of me.

On December 25, 2009, the Dutch Queen Beatrix, who often seems to act as the collective conscience of the Netherlands, delivered her traditional Christmas speech, as always on the subject of compassion. However, this time she said:

Technical advancement and individualization have made people more independent and distant. [...] Today, people are most of all concerned with themselves. We are inclined to look away from people and close our eyes and ears for the needs of others in our surroundings. Sometimes even our neighbours are strangers to us today. You speak to each other without having a conversation, you look at each other without seeing. People communicate through swift short messages. Our society is turning more individualistic by the day. [...] The emptiness cannot be filled with virtual encounters; on the contrary, distances will only be enlarged. [...] It

${ }^{5}$ Cf. Burn 2006, p. 86. As Pearce 2002, p. 113, has shown, games with a predetermined narrative plot contain six features: (1) a goal, (2) obstacles, (3) resources, (4) rewards, (5) penalties, (6) information. Myst is mentioned as one of the best examples (p. 116). Games like The Sims, Second Life and IMVU lack most of the distinct narrative features. 
only looks like modern technology is bringing people closer together, but in fact it keeps them at a 'safe' distance from one another, hiding behind their screens. Today, we can speak without showing ourselves, without being seen, anonymously. It has become easy to release your emotions in an inconsiderate and rude way. These days, nobody has to answer for disrespectful opinions anymore. ${ }^{6}$

Without any doubt, the Queen was talking about Short Message Services (SMS) for mobile phones, and social media like the Dutch Hyves, and the international Facebook and Twitter. When she spoke, the Queen herself was 71 years old and probably - like most old people - digitally illiterate. The following days, people started quoting and criticizing the Queen. Individualisation and social rudeness had started much earlier than she suggests: there is no reason to blame social media all of a sudden. Most people thought that social media, on the contrary, enlarged people's networks and brought congenial groups of people together. People responded that Beatrix herself could hardly be praised for her compassionate behaviour, unlike her mother, Queen Juliana; Beatrix has always been rather a distant queen herself. Besides, it remains to be seen whether there is a correlation between anonymity and rudeness.

One thing is for sure: maybe not the most reliable, but definitely the fastest news medium these days is Twitter. Let me give one example to clarify this. On Dutch Memorial Day, May 4, 2010, a large crowd gathered around the National Monument on Dam Square in Amsterdam, including the Queen and her family. During the ceremonial two minutes of silence, all of a sudden, a part of the crowd started panicking. Crush barriers fell over, people started running away, police escorted the royal family to safety in a hurry. Everyone seemed to be scared of an attack of some kind, like the one on Queen's Day, April 30, 2009, in the city of Apeldoorn, when a disturbed man drove his car into the crowd at high speed, in an attempt to hit the royal family. Just like then, everything was broadcast live on television. The only thing the viewer did not know was what happened. Soon an official statement on television explained that a man had become ill in the crowd. However, what we saw was a person being dragged away by several policemen.

The fastest medium to tell us what really happened was Twitter. A man standing nearby tweeted about a disturbed man, dressed in black like an Orthodox Jew, who started to scream like mad all of a sudden during the two minutes of silence. Someone instantly apprehended the drunk lunatic, while others fled (not least because there was a rumour about a bomb too). The message about the shouting man in black was retweeted many times within seconds, so in a few minutes everyone on Twitter knew what had happened. Much later, television, radio and finally the newspapers confirmed what people on Twitter already knew. A drunken and disturbed Dutch homeless man, dressed like an Orthodox Jew, who

\footnotetext{
${ }^{6}$ Translated from the original Dutch text by me (TM). Source: http://www.koninklijkhuis.nl/nieuws/toespraken/2009/december/kersttoespraak-2009/ (accessed 16 February 2012).
} 
did not even know there was a Memorial Day ceremony going on, had started to scream out of frustration and got himself arrested. Among the homeless people, the man's outfit earned him the name The Rabbi. ${ }^{7}$

Twitter is a virtual meeting place, where many of your friends are people you have never met personally. You just add people to your list of friends because you like their faces, their profile lines or their tweets that get retweeted by others, or because they get recommended by others through Follow Friday (\#FF). Some people you follow are real-life acquaintances, or famous journalists you consider reliable, and perhaps politicians, actors and authors. Everybody can read your tweets, everybody can start following you (although it is possible to block people or lock your account).

In 2010 the Library of Congress decided it was going to archive every tweet since the start of Twitter on March 21, 2006. Up to today, that would already mean billions of tweets. This large number of messages on Twitter can be accessed for historical and other scientific research. Google is developing a tool to search, select and replay what people said on Twitter. ${ }^{8}$

A very popular science at present in the Netherlands is Computational Humanities or e-Humanities: using computers in the humanities to answer scientific questions. This is still only a plan, but supposing you could study all the Dutch tweets for a certain period, imagine the questions you could automatically answer with computers. Along with linguists Marc van Oostendorp and Leonie Cornips, I have been thinking of researching the relationship between identity and behaviour on Twitter: ${ }^{9}$

1. The software should take a look at the avatar picture: is it the face of a human being on a passport-like photograph, or is it something else the person on Twitter may be hiding behind? I realise that the computer will not decide correctly every time, but still it would give useful results.

\footnotetext{
${ }^{7}$ His new nickname became the Dam-shouter. See: http://www.nu.nl/binnenland/2269067/damschreeuwer-wist-niet-herdenking-was.html $\mathrm{http} / /$ www.geenstijl.nl/mt/archieven/2010/05/damschreeuwer_is_een_dolle_fri.html http://www.elsevier.nl/web/Nieuws/Nederland/266128/Damschreeuwer-sprak-dreigendetaal-over-Beatrix.htm (all URLs accessed 16 February 2012).

${ }^{8} \mathrm{http}$ //www.guardian.co.uk/world/richard-adams-blog/2010/apr/14/twitter-library-ofcongress (accessed 16 February 2012). Twitter did recently change its Terms Of Service (restrictions on handing over data sets to third parties), which may hurt academic research. On the other hand, more tools are being developed to conduct any kind of research on data sets.

${ }^{9}$ Another Dutch-Flemish scientific initiative to analyse tweets is SoNaR, focusing on changes in contemporary written Dutch texts: see http://lands.let.ru.nl/projects/SoNaR/ and http://www.ru.nl/letteren/actueel/nieuws/redactionele/twitteren-wetenschap/ (accessed 16 February 2012).
} 
2. The software should decide whether we are dealing with a real human name or some kind of nickname. The computer will probably need lists of names to decide this, and again it will probably not decide correctly every time.

3. The software should judge the linguistic behaviour: is this person friendly or aggressive? The software can decide this by looking for expressions like "YOU BASTARD!!", which contains the three most obvious features of aggression:

- Capitals indicate possible screaming in anger.

- Exclamation marks, especially multiple ones, signify excitement and possible rage.

- The word "bastard" signifies the intention to insult.

Of course, the software will need to be enlarged with a lexicon of insulting words as well. Once again, the computer will not be $100 \%$ accurate in its analysis, because not every term of abuse truly has the intention to insult - words can be used playfully as well.

Still, I believe a computational approach can correctly interpret enough data to find out if the following hypotheses are true:

- Identifiable people on social media tend to react in a civilised manner.

- Anonymous people on social media, hiding behind, say, symbols and nicknames, tend to react impolitely.

In this way, the correlation Queen Beatrix presumed between online anonymity and aggression could be confirmed or falsified.

Another social network is Facebook, which is a less open system than Twitter. The fact that not everybody but only people who decide to become friends can read each other's short messages turns Facebook into a network with many closed circuits. Unlike on Twitter, most of the people on Facebook are known to you in real life: they are family, friends, colleagues, or acquaintances.

As an experiment, I decided to perform a pilot survey on my own friends. First I took a look at the pictorial representation of my 144 Facebook friends. ${ }^{10} \mathrm{I}$ did all the interpreting and counting by hand, because no software yet exists to do the job for me.

\footnotetext{
${ }^{10}$ I conducted this test on 3 February 2011. I mention a specific date because in time the number of friends can grow or shrink, and because pictures tend to change from time to time. Sometimes there is a game on Facebook where everyone is supposed to put up a childhood photo of themselves, or a picture of a famous look-alike. When I conducted the test, no such game was going on.
} 


\begin{tabular}{|l|l|c|c|}
\hline Pictorial representation of friends on Facebook & $\#$ & $\%$ \\
\hline & Face or otherwise recognisable (with family or friends) & 103 & 72 \\
\hline & Cartoon avatar, artist's impression of self & 0 & 0 \\
\hline & Recognisable detail of self & 0 & 0 \\
\hline & Unidentifiable (legs, shadow etc.) & 5 & 3 \\
\hline TOTAL & Empty, no picture & 9 & 6 \\
\hline PHEO's & Picture of somebody else (SuperMario, Jesus etc.) & 8 & 6 \\
\hline
\end{tabular}

It turns out that almost three-quarters (72\%) of my Facebook friends represent themselves as they are, with a passport-like photograph. A hundred percent of my Facebook friends identify themselves with their full name, but a little more than a quarter $(28 \%)$ decided to have themselves represented by an alternative picture or simply none. The people without an avatar picture are hardly active on Facebook. Twenty-two percent of my friends have chosen another picture than themselves: a picture from nature, an animal, a boat, a Celtic symbol, or a figure like Jesus or SuperMario. They are not hiding behind these pictures, because everyone can be identified by name - the pictures are merely representing some aspect of their personality they like to stress (for a while).

To study representations of people on Twitter, I took my own account again: I did not look at my followers (I have 453), just at the 451 people I follow and whose short messages appear in my timeline. ${ }^{11}$

\footnotetext{
${ }^{11}$ I conducted this test on 7 February 2011.
} 


\begin{tabular}{|c|l|c|c|}
\hline \multicolumn{2}{|l|}{ Pictorial representation of people on Twitter } & $\#$ & $\%$ \\
\hline & Face or otherwise recognisable (with family or friends) & 328 & 73 \\
\hline & Cartoon avatar, artist's impression of self & 15 & 3 \\
\hline & Recognizable detail of self & 10 & 2 \\
\hline & Unidentifiable (silhouette, hand, disguise) & 22 & 5 \\
\hline & Empty, no picture & 1 & 0 \\
\hline & Picture of somebody else (Brad Pitt, ugly person etc.) & 17 & 4 \\
\hline TOTAL & & 29 & 6.5 \\
\hline
\end{tabular}

Of course, on both Facebook and Twitter, I am a major factor in selecting people and filtering certain people out. In a research that will incorporate all users of these social media, or all users in a certain language, results will be different, for example because I may tend to avoid people with an empty profile or may tend to unfollow people with an annoyingly aggressive nature, such as people without humour or who are unable to put things in perspective.

When we compare my Facebook friends with my Twitter friends, it is eyecatching that an almost equal majority of people (72\% versus $75 \%$ ) present themselves with a recognisable photo, comparable to a passport photo. The remainder of my Twitter friends have again chosen another pictorial representation of themselves, such as cartoon avatars or artist impressions of themselves, pictures in disguise, silhouettes, pictures of art, cars, animals, or pictures from other people, ranging from extremely ugly people to Brad Pitt. 
Of all the 451 people I follow on Twitter, only eleven can qualify as people who mostly in a humorous or original way - like to use offensive or aggressive phrases:

\begin{tabular}{|c|c|c|c|c|c|c|c|}
\hline \multicolumn{2}{|c|}{$\begin{array}{l}\text { Names / nicknames of } \\
\text { writers of offensive tweets }\end{array}$} & $\begin{array}{c}\text { true } \\
\text { photo? }\end{array}$ & $\begin{array}{c}\text { true } \\
\text { name? }\end{array}$ & $\begin{array}{c}\text { male/ } \\
\text { female? }\end{array}$ & $\begin{array}{l}\text { right- } \\
\text { wing? }\end{array}$ & $\begin{array}{l}\text { journa- } \\
\text { list? }\end{array}$ & $\begin{array}{l}\text { \# of follo- } \\
\text { wers }^{12}\end{array}$ \\
\hline & @OllieVanOlaz & $\mathrm{Y}$ & $\mathrm{N}$ & M & $?$ & $?$ & 651 \\
\hline & @hoxha & $\mathrm{Y}$ & $\mathrm{N}$ & M & $\mathrm{Y}$ & $\mathrm{Y}$ & 3,375 \\
\hline & @baspaternotte & $\mathrm{Y}$ & $\mathrm{Y}$ & $\mathrm{M}$ & $\mathrm{Y}$ & Y & 5,556 \\
\hline & @ajboekestijn & Y & $\mathrm{Y}$ & $\mathrm{M}$ & Y & Y & 10,513 \\
\hline & $\begin{array}{l}@ \text { marnixamsterda } \\
\mathrm{m}\end{array}$ & $\mathrm{Y}$ & $\mathrm{N}$ & M & $\mathrm{Y}$ & $\mathrm{Y}$ & 1,459 \\
\hline & @bertbrussen & $\mathrm{Y}$ & $\mathrm{Y}$ & M & $\mathrm{Y}$ & $\mathrm{Y}$ & 6,205 \\
\hline & @Judge_Reef & $\mathrm{N}$ & $\mathrm{N}$ & M & $?$ & ? & 949 \\
\hline & $@$ Mutsaerts & $\mathrm{N}$ & $\mathrm{N}$ & $\mathrm{M}$ & Y & Y & 3,055 \\
\hline & @brusselmans & $\mathrm{N}$ & $\mathrm{N}$ & $\mathrm{M}$ & $\mathrm{Y}$ & Y & 5,392 \\
\hline & @drfreshbeef & $\mathrm{N}$ & $\mathrm{N}$ & $\mathrm{M}$ & $\mathrm{N}$ & $\mathrm{N}$ & 70 \\
\hline & $@$ DeHuisvrouw & $\mathrm{N}$ & $\mathrm{N}$ & $\mathrm{F}$ & $?$ & $\mathrm{~N}$ & 920 \\
\hline
\end{tabular}

${ }^{12}$ The numbers date back to 8 February 2011. 
1. @OllieVanOlaz. His photo may be real, his name is a variation on the brand name Oil of Olaz. In his profile, he characterizes himself as "Enfant Terrible 3.0".

2. @hoxha. Again his photo may be genuine, his name is a nickname. In his profile he calls himself a "marginal blogger" and he is linked to irreverent, young, right-wing Dutch emedia called PowNed and Geen Stijl.

3. @baspaternotte. Both photo and name are real. Political journalist of the liberal Dutch magazine HP-De Tijd. Friend of @bertbrussen, mentioned below.

4. @ajboekestijn. Again, both name and photo are genuine. Author and historian, writer of columns for the conservative Dutch magazine Elsevier.

5. @marnixamsterdam. The photo is real, the name is partly a nickname. Marnix Pauwels is the founder of the Dutch e-magazine Woedend!, which can be translated as "outraged".

6. @bertbrussen. Photo and name are real. Part of his profile states: "Certified New Bastard. Babyboombasher". Brussen is a journalist for the Dutch, right-wing e-magazine DeJaap.

7. @Judge_Reef. Neither photo nor name are genuine. Claims to be an editor.

8. @ Mutsaerts. Can be seen on the photo with a bag over his head. The name may be his family name. In his profile he calls himself a "pompous little ass". He writes for the Dutch, right-wing e-magazine Geen Stijl.

9. @ brusselmans. The name may be his family name. The photo shows a cup of coffee and the acronym LOL (for "Laughing Out Loud"). Again, he is a writer for the Dutch, rightwing e-magazine Geen Stijl.

10. @drfreshbeef. The profile states: "Eats heavy bricks, rubber tires and horses. Is kept at the Meertens Institute". The photo is false and the name is a nickname - behind it is a colleague of mine from the software development department. He is one of those people who like to make a blunt statement now and then (without becoming uncivilised) in anonymity.

11. @DeHuisvrouw. The only woman I follow on Twitter who tends to be truly sharp and sarcastic. The photo shows a hand pointing a middle finger and wearing a flowery ring. DeHuisvrouw means "the housewife" in Dutch. DeHuisvrouw is divorced with kids, unemployed, and lives in Antwerp, Belgium. A lot of her sarcasm concerns her own ineptitude at being a proper housewife, cleaning the house and raising the children.

One can conclude that the aggressive and offensive people I follow on Twitter are mostly young, right-wing males with a journalist background. A lot of their tweets can be judged as extrovert, aggressive and offensive towards others, for instance left-wing politicians. The only female in my list is much more introvert: her tweets are mainly sarcastic remarks about her own behaviour and that of her family members.

Based on my Facebook friends (who are never rude) and Twitter friends (who are sometimes rude), it would be wrong to conclude that Twitter is an excellent place to hide in anonymity and send offensive messages: at least the great majority of my Twitter friends (75\%) can be identified by their photo (and name), even 3\% more than on Facebook. On the basis of the people I follow (and this perhaps reveals more about my selections than about Twitter as a whole), it would be 
equally wrong to conclude that people with aggressive and offensive tweets try to hide behind the safe status of anonymity. To begin with, $98 \%$ of the people I follow hardly ever send aggressive or offensive tweets at all. The remaining $2 \%$ are not completely hiding. Fifty-five percent of these offensive users of Twitter show their real-life photo, although $73 \%$ do hide behind a nickname that does not entirely match their real-life name. In most cases it is not very hard to find out their real identities, though. To my mind, the Queen's erroneous impression about social media is mainly based on what she had heard about certain discussion forums that have nothing to do with Twitter or Facebook.

As soon as we have developed the research software, another interesting pilot project would be to see if the computer detects and selects the same offensive tweeters from the group of people I follow. ${ }^{13}$

\section{IMVU and Second Life}

Sometimes people on Twitter and Facebook play a certain role. For instance, there are Twitter fan accounts that just quote someone else's book, and there are some people who maintain a Facebook account for an animal or a baby. So not in all cases, but still in many cases, the real-life person and the virtual representation of that person are rather closely connected in Twitter and Facebook.

Unless they are posting links to more elaborate blogs, on Twitter and Facebook people do not tell long stories but just post short messages that could be interpreted as fragmented quotes from their life story. Together with their pictures, profile lines and microblogs, the ethnological fieldworker can gather rich harvests of ultrashort personal narratives from cyberspace for free.

Next in the online universe are instant messaging services like MSN and MMORPGs such as Ultima Online, EverQuest, World of Warcraft, or Age of Conan. In these role-playing games ${ }^{14}$, the scenery and the plot are more or less predefined $^{15}$, and so are the characters. There are only a few basic characters to choose

${ }^{13}$ A human being will usually be unable to read all the tweets of all the people he follows. It is possible that a computer will detect offensive tweets from people who hardly send tweets and therefore failed to gain the reputation of an offensive tweeter from the reader's point of view.

${ }^{14}$ See "playing tales" in Meder 2008, p. 494 and the study by Trippe 2009 that specifically focuses on the 18+ MMORPG called Age of Conan, introduced in May 2008.

${ }^{15}$ Both online and offline adventure or role-playing games have pre-defined storylines, and Veugen 2004, p. 92 calls them "interactive comics". Cf. Dormans 2004, p. 123, DeuberMankowsky 2007, pp. 101-102, Pearce 2002, p. 116, Tavinor 2009, pp. 2, 20, 119-129, 203. Also see Burn 2006, pp. 77, 79-80 and 86 (on linear plotlines, and the influence of American comics and Japanese manga and anime). Burn (p. 86) quotes a player called Ben: " 'One of the problems with Final Fantasy is ... it is really linear, but they make it seem like it's not.' In fact, he says, there is 'only one place you can go to'.” 
from, and a person can gain more individual personality in the course of the game. In World of Warcraft you have to choose from the start whether you want to be a gnome, a human or a dwarf, a goblin, an elf or a troll, a warrior, a druid or a mage, a hunter or a healer, etc. (cf. Trippe 2009, pp. 12-13; Deuber-Mankowsky 2007, p. 102). Since these different characters have different skills, the adventures can differ as well: particularly in this kind of games, people tend to create several accounts in order to experience different adventures. Nevertheless, all the characters are part of the World of Warcraft realm and remain limited to the intentions of the game designers (cf. Burn 2006, pp. 76-80). If you do not like to be sent from one place to another to fulfil some request or assignment, if you do not like to team up with people to fight all kinds of adversaries to the death, and if you do not like to die on a regular basis either, then WoW just is not your kind of game.

At the other end of the spectrum there are social games like IMVU and Second Life, both with millions of subscriptions (of which many are inactive) and with about 100,000 and 30,000 people respectively online at any given time ${ }^{16}$ : their creators offer no pre-programmed scenario whatsoever, there are no levels or goals to reach, there is no end to the game and you cannot die. Therefore, it can hardly be called a game: it is more like chatting, albeit with animated avatars in a 3D environment. ${ }^{17}$ Soon, however, both avatars and scenery can develop in personality and shape, and storylines evolve almost naturally. In IMVU the characters are more or less restricted to a humanoid form: it is possible to grow wings and turn into an angel, or grow teeth and become a vampire. Second Life goes further: there you can turn into a horse or a dragon as well. ${ }^{18}$

Let me first introduce both games a little, beginning with IMVU. What the acronym means is "Instant Messaging Virtual Universe", which again confirms how much chatting is the key action here. Once you join IMVU, you get to choose from a limited number of male and female avatars: ten young, mature women and ten young, mature men - in both cases nine white (including one possible Latino), one black and none Asian. You make up a (fantasy) name for yourself: it is fashionable to present yourself as bad or sexy, so names with dark, devil, evil, death, bitch, sexy, hot and $\mathrm{xxx}$ are popular. Once inside, you can always change your looks - you had better do so if you do not want to get recognised as a newbie or "noob". After joining, you get a standard house with furniture and you get a wardrobe with some extra clothes. If you want to have more houses or inventory items, want to play music online, want dances or other non-standard action

\footnotetext{
${ }^{16}$ Castronova 2008, p. 32 for SL. The number of online IMVU players is mentioned in the program at all times.

${ }^{17}$ That does not mean that programs like SL and IMVU are completely realistic. As Steven Pools says: "We don't want absolutely real situations in videogames. We can get that at home"; cited by Dormans 2004, p. 122.

${ }^{18}$ It seldom happens that people remain horses or dragons all the time, though - it is mainly supposed to be a gimmick, and people tend to return to their humanoid form (counting nekos, furries, angels and vampires as humanoid too).
} 
movements, or want new shapes, skins, clothes and accessories, you will have to pay for them with credits, which you can either earn or buy with real money. Once inside IMVU, you skip from one place to another: inside a room or landscape you jump from yellow dot to yellow dot, while you beam yourself from one room to another.
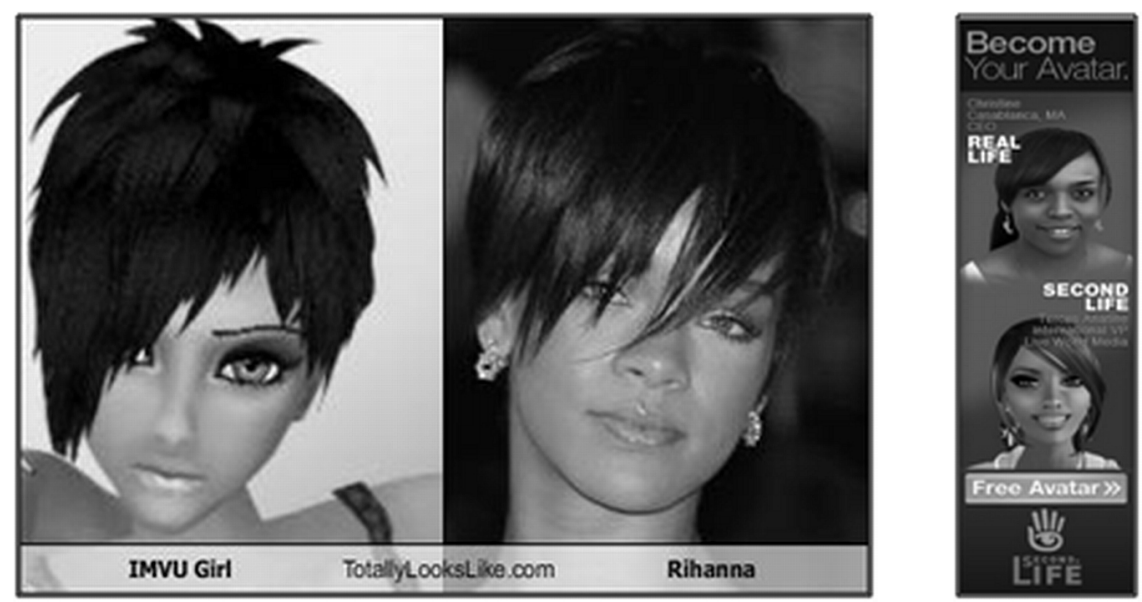

Become your avatar: IMVU and Second Life (SL)
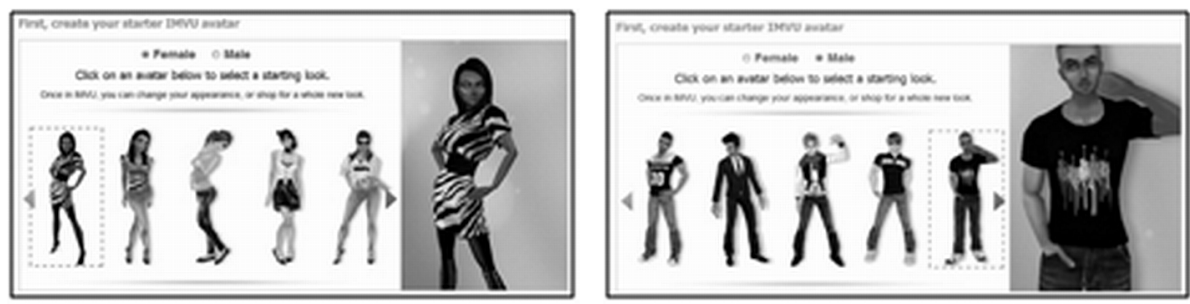

$I M V U=$ Instant Messaging Virtual Universe (female and male start)

The most usual conversation in IMVU is one-on-one. You find friends by chatting with people: this can be done at random, or because you see the other is from a certain country, speaks your language, shares your interests and so on (the standard language is English, but Spanish, French, Italian, German, Portuguese and Japanese are important as well). Every user gets an hp (homepage) for selfpresentation. Some users keep their homepages very brief for privacy or safety reasons while others provide full information about (the likings of) the avatar and/or the owner, including wallpapers, favourite music, pictures, stickers, video clips from YouTube, etc. There are chat rooms as well, where groups of friends, or people with mutual interests, meet: most of the time, the number of avatars in one room on IMVU is technically limited to ten.

There is one important feature of IMVU that I have not mentioned yet: the Access Pass (AP). You can only buy it for twenty dollars via credit card with a 
proof that you are over 18. Once you have your AP, you are allowed to see all the restricted adult pages and items, such as nude skins, (limp) dicks and lovemaking movements. Of course, a lot of people on IMVU will assure you that they are not interested in cybersex, but fact is that quite a lot of adults visibly own an AP anyway. Let us say it works as a seal of quality for mature interaction.

The idea of chatting with avatars in IMVU and Second Life is basically the same. SL is not divided into rooms, but into 3D worlds you can really walk around in: no need for jumping from spot to spot. It is possible to teleport between distant islands and in many places you can even fly like Superman. There are a few obvious differences between IMVU and SL:

- IMVU states that their "core members are young adults age 18-24" (while a minority of $7 \%$ is $35+) .{ }^{19}$ Important players of IMVU seem to be adolescent girls who like to dress up their avatar. The focus in SL is a little more mature and deals with exploring worlds. ${ }^{20}$ The core group in SL is aged between 25 and $34(40 \%$; the group of $35+$ is much larger in SL at $33 \%$ ). In $2007,41 \%$ of the players were female and $59 \%$ were male (although the number of female avatars in use is traditionally somewhat higher). ${ }^{21}$

- As far as mature content is concerned, SL is less restrictive than IMVU. In SL you do not have to buy an Access Pass, but you have to prove you are $18+$ to be able to enter the mature areas.

- Clothes, music, rooms, and furniture can be obtained for free ${ }^{22}$ if you like in SL, but you have to pay rent if you want to own land and put a house there. Still, if you like, you can live in SL for free (I am a freeloader, for instance, who used to live in a tent near Stonehenge ${ }^{23}$ ).

\footnotetext{
${ }^{19}$ See http://www.imvu.com/about/faq.php (accessed 16 February 2012).

${ }^{20}$ Apart from escape, social interaction and amusement, exploration is mentioned by Trippe 2009 as one of the important motivations to play online games. Other motivations mentioned, especially for participating in MMORPGs, are teamwork, the satisfaction of feeling in power and the gratification of successful competition (pp. 41-48; cf. Pearce 2002, p. 116 on discovery as a "fundamental quality of play"); the latter motivations are less applicable to SL and IMVU. Average age in a MMORPG like Age of Conan is 31. The core group (49\%) is aged $20-29$ years old $(19 \%$ is $30+)$. No less than $92 \%$ of the players are male. Trippe 2009 , p. 66, 87.

21 See http://static.secondlife.com/_files/xls/SL_Virtual_Economy_Metrics_02-02-07.xls (last accessed 7 April 2011). Still, the number of female players in IMVU and SL is higher than in MMORPGs and other more masculine action games: Timroff 2007, p. 15. In most countries, gaming women form a minority, though their numbers are rising: Walter 2002, pp. 39-40; Deuber-Mankowsky 2007, p. 101.

${ }^{22}$ Quality products cost money, unsurprisingly.

${ }^{23}$ I lived there since 2007 , but in 2011 the place got sold and partly vanished.
} 
- In an SL sim or world, many more avatars can get together than in IMVU: during live concerts or when xploders pay out, an SL place can take between fifty and a hundred residents before it is full.

- In SL you do not get a whole homepage on the Internet, but just a small 'inworld' profile where you can leave two photos and some text about your avatar and your first life.

- It takes more skill to navigate through SL: the software is more complicated than in IMVU.
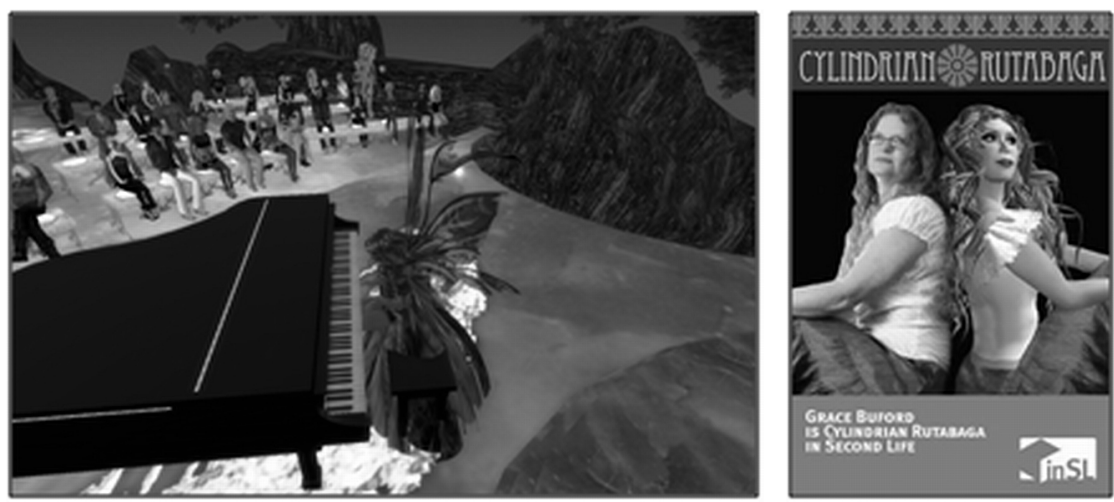

A live concert of Cylindrian Rutabaga (Grace Buford) in SL

Compared to IMVU, there is a little less white dominance in Second Life in the initial choice of avatars. The division between male and female avatars is equal in both games. Just as in IMVU, you can opt for one black male or female in SL. Avatars with visibly Asian features are the least popular in both IMVU and SL; only SL offers you a choice between two types of Asian males (both looking a bit nerdy).

\begin{tabular}{|llcccc|}
\hline Initial avatars & gender & number & white & black & Asian \\
\hline IMVU & female & 10 & 9 & 1 & 0 \\
& male & 10 & 9 & $1(?)$ & 0 \\
SL & female & 6 & 5 & 1 & 0 \\
& male & 6 & 3 & 1 & 2 \\
\hline
\end{tabular}

The dominance of white avatars to start with is rather obvious, ranging from $50 \%$ of the males in SL to $90 \%$ of the males and females in IMVU. ${ }^{24}$

${ }^{24}$ In most (offline console) adventure games, players normally are not able to choose gender or ethnicity. In the 1990s, heroes were predominantly white males. In recent games, 


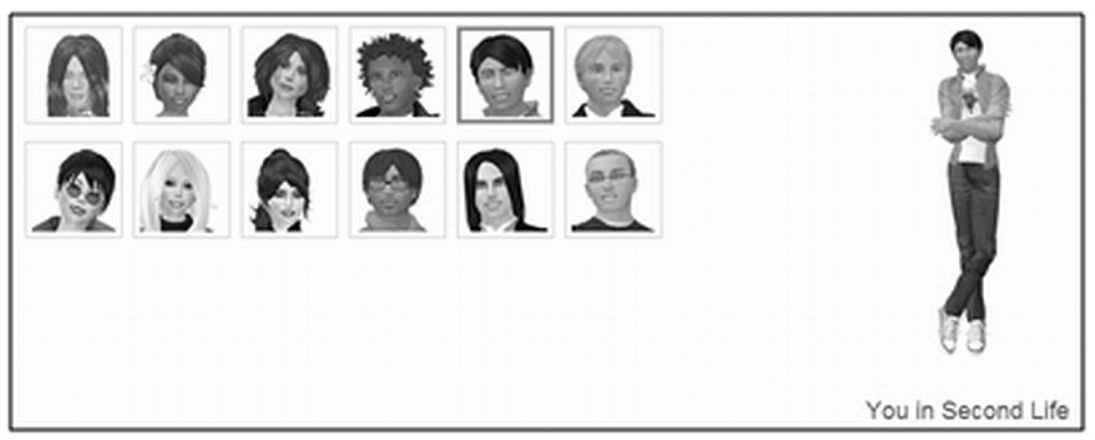

Gender and ethnicity: avatars in $S L$

In order to avoid being an obvious noob, people soon start reshaping their looks and building an individual personality. Inside SL (and the same goes for IMVU) white skins and shapes can be found in abundance. Asian skins and shapes, on the other hand, appear to be scarce, while new African shapes and skins can hardly be found. One would expect that if everyone were faithful to his or her own ethnic features, the actual division of race in both games would be more or less equal (33\% each), considering the fact that there are lots of American computers online, as well as computers in Japan, China, Singapore, Taiwan and South Korea. However, the attraction of SL is precisely that you do not have to stick to your race - or even gender, for that matter. The population in SL looks predominantly white, so the supply of skins and shapes must somehow reflect an existing demand. Many people tend to shift their looks and shapes towards the European type, which is apparently considered an ideal. Perhaps people like to keep some part of their outer appearance. Blacks keep their hair black, but now straightened. My avatar usually wears glasses, though most avatars do not. I should add that many Asian players have a distinct preference for avatars with manga features, stylised with big round eyes and dressed in particular clothes, for instance the "gothic Lolita" style, which is popular among Japanese youth and can be found in Japanese manga and anime everywhere.

I talked to several Afro-American and Asian people about their rather European looks, and the answers varied from coincidence or a mistake to a deliberate makeover. A Malaysian girl from Kuala Lumpur, who called herself Casis, had Asian features in real life but gave her avatar European looks and literally confessed: "This is my dream." I believe that in every avatar there are some hidden wishes come true.

more white female characters were introduced, up to a 50-50\% distribution for the leading heroes, but the white male still remains a dominant character when more roles are considered. Less submissive female characters can be found in modern games. Both men and women are stereotypically portrayed as muscular or sexy. Other ethnicities remain a minority. See Jansz \& Martis 2003. 
In SL there are many worlds to explore. They are so numerous that it would be impossible to visit them all. The first places you come across are the welcome areas, where the newbies arrive and sometimes get help from experienced residents. Then there are the many shopping malls, where you can buy clothes and stuff. Furthermore, there are the natural environments (parks, woodlands, beaches) and inner cities (Amsterdam, Paris, Athens). Probably the most important meeting places are the clubs: the ballrooms (with dress code), jazz clubs, discotheques, rock cafés and strip clubs. Then there are the adult places where people can have cybersex, with all (un)thinkable sexual preferences available. ${ }^{25}$ Still, most of the land in SL is simply used for living in houses.

There are many activities possible in SL. My favourites are exploring worlds, dancing, chatting, visiting live concerts, photography, treasure hunting and flying on Pegasus. Other possible activities are parasailing, parachute jumping, scuba diving, role-playing, visiting museums, marrying and having kids or just having sex. As far as the last options are concerned: quite a few people fall in love online and have a virtual wedding (I was invited as a guest once). IMVU claims they have twenty marriages a day.

Sometimes the couples have kids afterwards. In SL, women first buy a pregnant shape, and then buy a virtual baby ${ }^{26}$, and later couples may want to adopt someone with a child avatar who is happy to be their kid. Not all couples get married and have kids or even go on to live together virtually. Either way, relationships show that time in the virtual world goes much faster: a day counts for a week, a week for a month, and a month for a year. It is said that on average, a virtual relationship lasts for about three to four real months, married or not. As far as sex is concerned, the way people dress in IMVU and SL shows a distinct sexualisation of the virtual world: the numbers of high heels and short skirts, as well as tattoos and muscles, or leather and latex are way above average. Although people may not admit it, being attractive to others seems to be an important goal. ${ }^{27}$

Second Life came online in 2003 and IMVU in 2004. Since then, game-specific jargon and abbreviations have emerged, such as 'noob' for newbie, 'lag' for slow data traffic, and 'rezzing' for becoming visible.

\footnotetext{
${ }^{25}$ As far as extremes go, BDSM (bondage and sado-masochism) and forms of slavery (subs and doms, Gorean slaves and masters) seem to be rather popular - cf. Timroff 2007, p. 142. ${ }^{26}$ It is also possible to buy a complete pregnancy all at once.

${ }^{27}$ Castronova 2008, pp. 52-54 on sexualisation. Cf. Timroff 2007, pp. 131-148 on sex and relationships in SL, and on pp. 146-147 a description of his own first romance and break-up - after this, he decided to become a zebra. Also see Pfeijffer 2007, pp. 77-80, 103-106 on SL marriage (and real-life jealousy).
} 


\begin{tabular}{|c|c|c|c|}
\hline Word & Meaning & Word & Meaning \\
\hline age play & $\begin{array}{l}\text { using a child avatar, esp. for } \\
\text { sexual purposes }{ }^{28}\end{array}$ & neko & cat-like avatar and style \\
\hline alt & $\begin{array}{l}\text { alternative, second (third } \\
\text { etc.) avatar }\end{array}$ & parcel & a piece of land \\
\hline avi, ava & $\begin{array}{l}\text { avatar, the player's virtual } \\
\text { character }\end{array}$ & PG & $\begin{array}{l}\text { parental guidance sim: no } \\
\text { mature content allowed }\end{array}$ \\
\hline bot & $\begin{array}{l}\text { robot avatar, programmed to } \\
\text { act without human guidance } \\
\text { at the keyboard }\end{array}$ & poseball & $\begin{array}{l}\text { pink (f) and blue }(\mathrm{m}) \text { balls to } \\
\text { be used for animation, like } \\
\text { dancing }\end{array}$ \\
\hline camping & $\begin{array}{l}\text { getting paid for hanging } \\
\text { around and adding to the } \\
\text { popularity of a place }\end{array}$ & prim & $\begin{array}{l}\text { a primitive shape, counted } \\
\text { like bits or bytes }\end{array}$ \\
\hline (to) cyber & to have cybersex & (to) rezz & $\begin{array}{l}\text { to get resolution, to become } \\
\text { visible }\end{array}$ \\
\hline furry & animal avatar with fur & rezzday & $\begin{array}{l}\text { SL birthday, the day an } \\
\text { avatar got resolution, came to } \\
\text { life }\end{array}$ \\
\hline full perm & $\begin{array}{l}\text { full permission to copy, } \\
\text { modify and transfer }\end{array}$ & sandbox & $\begin{array}{l}\text { place where it is allowed to } \\
\text { create, build and open boxes } \\
\text { with goodies }\end{array}$ \\
\hline $\begin{array}{l}\text { Gor (adj. } \\
\text { Gorean) }\end{array}$ & $\begin{array}{l}\text { Fantasy world of masters } \\
\text { and slaves }\end{array}$ & $\operatorname{sim}$ & $\begin{array}{l}\text { a simulation, an SL island or } \\
\text { piece of land }\end{array}$ \\
\hline griefer & harassing resident & SLurl & $\begin{array}{l}\text { The URL (location) of a Sim } \\
\text { in SL }\end{array}$ \\
\hline lag & $\begin{array}{l}\text { slowness in visualization, } \\
\text { movement and/or text }\end{array}$ & xploder & $\begin{array}{l}\text { machine paying } \mathrm{L} \$ \text { to } \\
\text { playing avatars present }{ }^{29}\end{array}$ \\
\hline Lindens & Linden dollars, SL money & Zyngo & $\begin{array}{l}\text { slot machine playing a kind } \\
\text { of bingo }\end{array}$ \\
\hline
\end{tabular}

The abbreviation 'brb' means be right back, and a 'tp' is a teleport. Not all the abbreviations are game-specific; for example, 'lol' and 'rofl' are commonly used in all kinds of short messaging. ${ }^{30}$

\footnotetext{
${ }^{28}$ Tavinor 2009, pp. 152, 161, 169 seems to be rather obsessed with marginal phenomena like age play in Second Life. In his study, Tavinor is more interested in the action-packed video games.

${ }^{29}$ Active xploders can be found here:

http://serv.tmyentertainment.com/xploders/trackerLight (accessed 16 February 2012).
} 


\begin{tabular}{|c|c|c|c|c|c|}
\hline Abbrev. & Meaning & Abbrev. & Meaning & Abbrev. & Meaning \\
\hline AP & $\begin{array}{l}\text { Access Pass } \\
(18+)\end{array}$ & i c & I see & rofl & $\begin{array}{l}\text { rolling on the } \\
\text { floor laughing }\end{array}$ \\
\hline avi, ava & avatar & $\mathrm{idk}$ & I don't know & roflmao & $\begin{array}{l}\text { rolling on the } \\
\text { floor laughing my } \\
\text { ass off }\end{array}$ \\
\hline afk & $\begin{array}{l}\text { away from } \\
\text { keyboard }\end{array}$ & ik & I know & tc & take care \\
\hline bf & boyfriend & IM & $\begin{array}{l}\text { Instant } \\
\text { Messaging } \\
\text { (private } \\
\text { messages) }\end{array}$ & TGIF & $\begin{array}{l}\text { Thank God it's } \\
\text { Friday }\end{array}$ \\
\hline brb & be right back & $\mathrm{LS}$ & Linden dollar & tp & teleport \\
\hline brt & be right there & $\operatorname{lm}$ & $\begin{array}{l}\text { landmark (the } \\
\text { SL url of a } \\
\text { place you can } \\
\text { teleport to) }\end{array}$ & $\mathrm{ttfn}$ & tata for now \\
\hline gf & girlfriend & $\operatorname{lmao}$ & $\begin{array}{l}\text { laughing my } \\
\text { ass off }\end{array}$ & $w b$ & welcome back \\
\hline g2g & got to go & lol & $\begin{array}{l}\text { laughing out } \\
\text { loud }\end{array}$ & wtf & what the fuck \\
\hline hp & homepage & omg & oh my God & wtg & way to go \\
\hline HUD & $\begin{array}{l}\text { Head Up } \\
\text { Display }\end{array}$ & $\mathrm{rl}$ & real life & yw & you're welcome \\
\hline
\end{tabular}

In many cases, the virtual representation of people stays close to the original: people tend to create a slightly improved version of themselves (Castronova 2008, p. 8): a little younger, a bit slimmer, somewhat more attractive, always healthy and immortal. In a Dutch survey the division between "looks like me" - "does not look like me" was $58 \%$ versus $42 \%$ (Timroff 2007 , p. 71). The most striking difference with Twitter and Facebook is that people are extremely reluctant to publish their real name and personal details, and most people claim they want to keep their first life private. This is not entirely true, because in many cases once you get to know people their first life is the main topic of conversation.

The identification between player and avatar can become very tight. The most striking example I experienced in SL was when people could earn Linden dollars while camping on a nudist beach, provided they took off all of their clothes.

${ }^{30}$ Cf. Timroff 2007, pp. 180-186, Pfeijffer 2007, pp. 111-124, Bronner 2009, pp. 60-62 and Trippe 2009, pp.12, 18-19 on online chat lingo and the use of emoticons. For internet slang see http://www.wordiq.com/definition/Chatspeak (accessed 16 February 2012). 
Several girls refused to undress their avatars, even though they wanted to earn money badly. Their distinct feelings of shame at exposing their naked physical bodies in public had extended to their pixelated avatars: their virtual and real body had practically become one as far as feelings of discomfort and shame about public nudity were concerned. ${ }^{31}$

Still, there are also people who do not stay so close to their first lives. ${ }^{32}$ They join one of the subcultures in IMVU or SL. The largest groups are:

- Gor: role-play of masters and slaves in a traditional tribal society ${ }^{33}$

- Bloodlines: role-play of vampires and lycans (werewolves). ${ }^{34}$ In both IMVU and SL the vampire role-play is getting more popular again since the True Blood television series (2008) and the Twilight movie saga (2008).

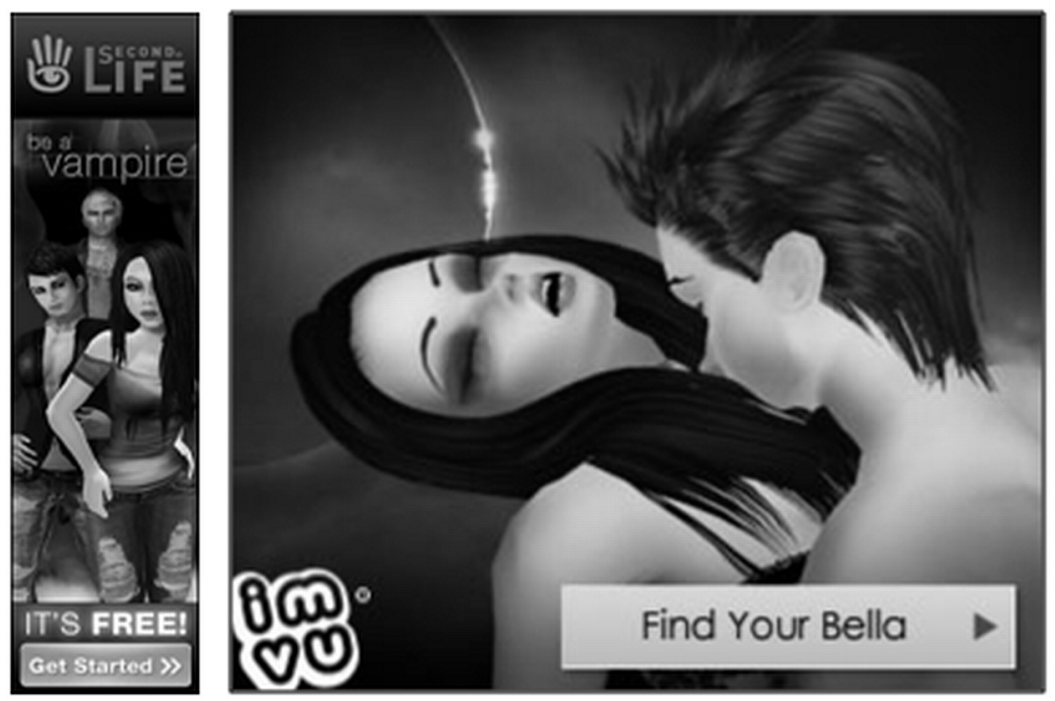

Increasing popularity of vampires in SL and IMVU

\footnotetext{
${ }^{31}$ On the process of identification and involvement by the player with the avatar, see Butler 2004, pp. 107-108, Burn 2006, pp. 82-85 and Pfeijffer 2007, pp. 85-88.

${ }^{32}$ Cf. Fine 2002, p. 207 concluding for Live Action Role Playing (LARP): "The gamer plays the game as himself, while the player who wishes to lose himself to the fantasy is the true role-player - he plays the character."

${ }^{33}$ Based on the novels by John Norman on the planet of Gor. See Pfeijffer 2007, pp. 45-48, and also http://www.magdalenasiemens.com/tag/second-life-gor/ (accessed 16 February 2012).

${ }^{34} \mathrm{http} / / / \mathrm{www} . s \mathrm{lbloodlines.com}$ (accessed 16 February 2012). This is the only group I joined for a while. I was the human blood donor of my vampire mistress Freya (in real life a piano teacher from Croatia) of the Veiled Fang Clan.
} 
- Neko: the Japanese word for cat. It is a fashion style; nekos do not role-play in groups, individual nekos just act like cats. Nekos are human in physiology, they just wear cats' ears, tails and whiskers.

- Furry: anthropomorphic character, part human, part animal. In many cases, furries look like dogs, goats, wolves or foxes. ${ }^{35}$ They can form a group in SL, but that is not necessary. ${ }^{36}$

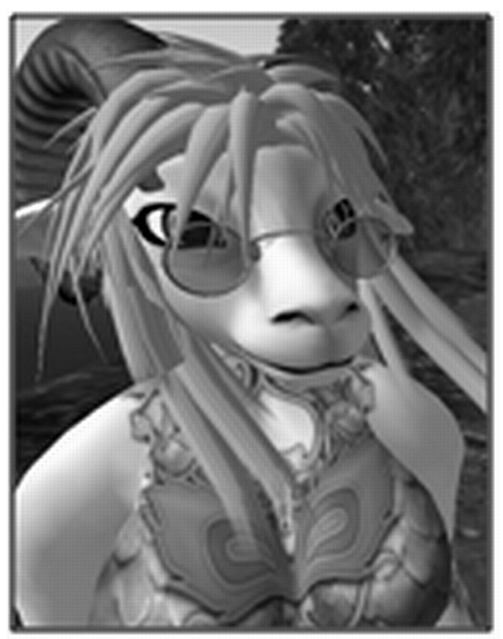

Korii (USA) as a goat

Besides belonging to one of these subgroups, people can act like specific superheroes, cartoon figures, heroes from novels or movies and video game characters; here I mention Superman, Batman, Darth Vader, Fred Flintstone, Tintin, Sonic, Snoopy, Super Mario, Alice, and a crew member from Star Trek's Voyager.

Another part of role-playing is gender bending: women playing men, and men playing women. Depending on the survey, $3-4 \%$ of the women confess they use a male avatar, while $6-14 \%$ of the men admit they have a female avatar (Timroff 2007, pp. 140-141). Women developers and models often have male avatars as well, because they need them in designing and photo shoots. The same goes for male developers and female avatars of course, but it looks like men act as women more often either to flirt with other men or lesbian women, or earn money as an

\footnotetext{
${ }^{35}$ Furry fandom does exist outside SL as well: http://en.wikipedia.org/wiki/Furry_fandom (accessed 16 February 2012).

${ }^{36} \mathrm{I}$ once asked an American neko and furry called Tenyan if the animal shape was a strategy to avoid cybersex. She denied this and stated that furries in SL mate at least as much among each other as humans do.
} 
escort. ${ }^{37}$ Or just to experiment with how it feels to look and act like a woman Dutch male poet, novelist and journalist Ilja Leonard Pfeijffer wrote columns and a book (Pfeijffer 2007) on his adventures as a tall redhead called Lilith Lunardi. ${ }^{38}$

Furthermore, it is not uncustomary to have one main character, and next to that one or more alts - alternative, secondary avatars - male or female. The alts can be used for boring jobs like hanging around for money, for the naughty stuff, or for being online without your friends noticing and bothering you.

As far as my own conduct is concerned, I cannot stay with groups for long and I tend to move on after a while. To avoid getting stuck with a group forever, it is best to stop for a while and change to a new account. I feel my best wandering around like a loner, I enjoy creating new avatars and I prefer not to stick with one personality the whole time. Nevertheless, most of my avatars look more or less the same: a younger, Mediterranean version of myself: a bit slimmer and taller, slightly more muscles, long black hair, and - most of the time - glasses. Again, an improved and idealized version of myself.

As a matter of fact, large parts of people's virtual lives are slightly improved and idealized versions of their own lives (Timroff 2007, p. 135). A Dutch woman calling herself Marinka lived in an apartment in The Hague, but in SL she bought land on an island near the sea, and lived there in a white house beside the beach, with a horse in her backyard, just as she always dreamed. The house was a realistic representation of a normal house, with a kitchen, bathroom, and bedroom, all superfluous because an avatar never needs to eat, wash, or sleep (cf. Pfeijffer 2007, pp. 33-36).

"You have to make up your own story here," Anky told me. She is a 53-yearold Dutch woman, one of the oldest people I met in SL. In many cases, these stories resemble people's own life stories - Anky too mainly told me about her family life, her husband's ill health, her daughters' relationships and their hardships with the crisis and a double mortgage.

Still, there are parts of IMVU and SL reserved for role-play, with rules and dress codes and all. In sims resembling the Middle Ages you can encounter orcs, trolls and fairies role-playing to recreate a Lord of the Rings-like atmosphere. Wonderland is shaped after the books of Lewis Carroll, and characters like Alice and the Mad Hatter re-enact their adventures. There are sims recreating prerevolutionary France, and there are steampunk worlds. This does not mean that everybody is always working on a storyline. Characters in these sims too may forget to play-act and start telling you about their personal lives.

${ }^{37}$ In more violent role-playing games like Anarchy Online players apparently believe that many of the female avatars are played by (middle-aged) men, especially because women have the reputation of not playing these violent games. Burn \& Carr 2006, pp. 112-113, Carr 2006, p. 167.

${ }^{38}$ The photo album of Lilith Lunardi still exists here: http://www.flickr.com/photos/lilithlunardi (accessed 16 February 2012). 


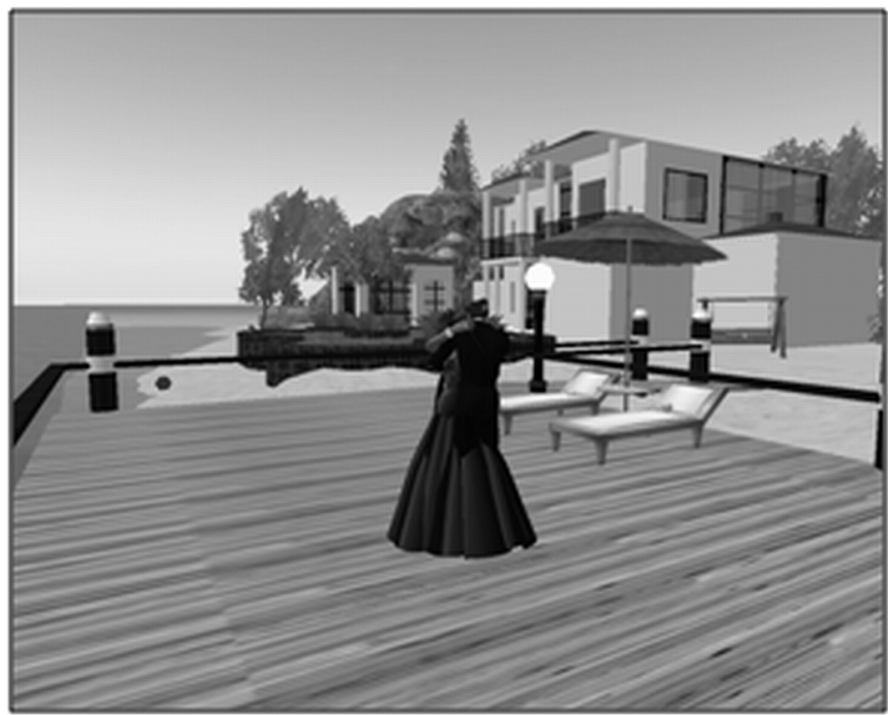

Dancing with Dutch Marinka in front of her dream house

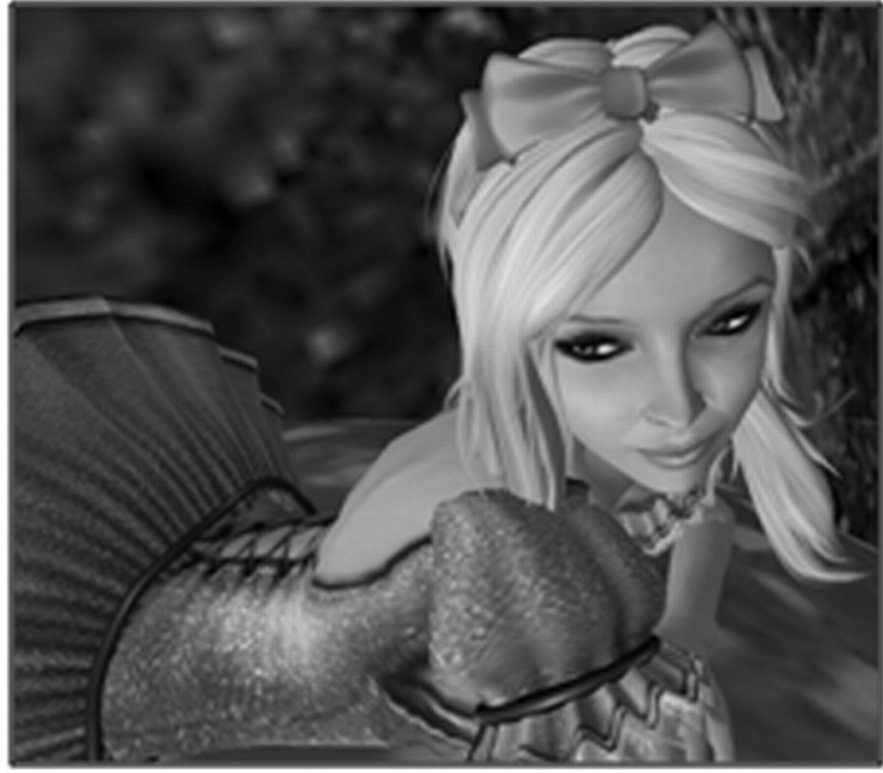

Lucky, a psychology student from Memphis, playing Alice

A final question: did I ever meet, in real life, anyone I met in IMVU or SL first? I did once. A Dutch lady, calling herself Sjumpie online, sang in a gospel choir, and my wife and I visited several of the concerts, and we talked to her during the break. But she was an exception. I never met anyone else from IMVU and SL in real life. 
The games are not designed for real-life dating anyway, although sometimes people do decide to meet.

\section{Conclusion}

Our lives online are not something separate from our lives offline: both are an inherent part of our existence..$^{39}$ In both realms we act, react, play roles and make choices about our representations.

For most people, both Twitter and Facebook are just modern ways of representing and expressing oneself. People make choices about what information to provide and what photos to show and what not. In contrast to what our Queen suggests, Twitter and Facebook are not breeding places for anonymous insulting. There certainly is some occasional insulting going on both on Twitter and on Facebook, but this ordinarily happens quite openly.

The role-playing in IMVU and SL is part of the player's personality. Both social games give the opportunity to present a somewhat improved or even dreamed-of version of oneself. Playing the game may be called an escape, but so is first-life vacation, reading a novel, going to the movies, shopping and having a beer in the pub. ${ }^{40}$ IMVU and SL can be called games, but in a sense they are not there is no plot, no level, no mission, no end. ${ }^{41}$ Nevertheless, man is a homo ludens and a homo narrans, so people readily start to play and unfold narratives in the online world. Social games like IMVU and SL are excellent platforms to express and shape our ideals and fantasies. ${ }^{42}$

All this communicating, role-playing, self-representation, and narrating, be it online or offline, is part of our modern human existence.

\footnotetext{
${ }^{39}$ Cf. Blank 2009, p. 8: "the cyberfield is increasingly engaging humans despite its liminal state" and p. 11: "the Internet's 'field' cannot be separated from the traditional field to which folklorists are accustomed. [...] Both have folk groups, customs, lingo and dialects, neighborhoods, crimes, relationships, games, discussion groups, display of emotion, banking, commerce, and various other forms of communication and education."

${ }^{40}$ Cf. Trippe 2009, pp. 38-40 and Timroff 2007, p. 132. I do not agree with Butler 2004, pp. 115-116 who compares computer games to virtual drugs.

${ }^{41}$ Still, Tavinor 2009, pp. 87-88, 108, 201 speaks of 'freeplay'. Several (offline) simulation games have no levels or final goal either, and hardly any plot, like The Sims and Simcity see Atkins 2003, pp. 111-137. Rather simple online (Facebook or Myspace) games resembling IMVU and SL are Habbo (since 2000, for teens) and Woozworld (since 2009, for "tweens and teens" of 9-14 years old). No software download is needed to play these games.

42 While Castronova 2008 looks at these virtual surroundings as new fun economies, Tavinor 2009 looks at them as pieces of art, and Atkins 2003 as fictional (narrative) forms that one can "read" (p. 154).
} 


\section{References}

Atkins, Barry (2003): More Than a Game. The Computer Game as Fictional Form. Manchester: Manchester University Press.

Blank, Trevor J. (2009): Introduction. In: Trevor J. Blank: Folklore and the Internet. Vernacular Expression in a Digital World. Logan: Utah State University Press, pp. 1-20.

Bronner, Simon J. (2009): Digitizing and Virtualizing Folklore. In: Trevor J. Blank, ed.: Folklore and the Internet. Vernacular Expression in a Digital World. Logan: Utah State University Press, pp. 21-66.

Burn, Andrew (2006): Playing Roles. In: Diane Carr, David Buckingham, Andrew Burn, Gareth Schott: Computer Games: Text, Narrative and Play. Cambridge: Polity Press, pp. 72-87.

Burn, Andrew; Diane Carr (2006): Motivation and Online Gaming. In: Diane Carr, David Buckingham, Andrew Burn, Gareth Schott: Computer Games: Text, Narrative and Play. Cambridge: Polity Press, pp. 103-118.

Butler, Mark (2004): Zur Psychodynamik des Computerspielens - Zwischen Perversion, Psychose und Rausch. Figurationen: Gender, Literatur, Kultur 5 (2004) 1, pp. 103-119. (Theme issue on games).

Cameron, James, director (2009): Avatar. Twentieth-Century Fox.

Carr, Diane (2006): Games and Gender. In: Diane Carr, David Buckingham, Andrew Burn, Gareth Schott: Computer Games: Text, Narrative and Play. Cambridge, Polity Press, pp. 162-178.

Castronova, Edward (2008): Exodus to the Virtual World. How Online Fun is Changing Reality. Houndmills: Palgrave Macmillan.

Deuber-Mankowski, Astrid (2007): Das virtuelle Geschlecht. Gender und Computerspiele, eine diskursanalytische Annäherung. In: Christian Holtorf, Claus Pais, eds.: Escape! Computerspiele als Kulturtechnik. Köln: Böhlau Verlag, pp. 85-104.

Dormans, Joris (2004): Volstrekt realistische situaties in computergames? Die hebben we thuis al. In: Tijdschrift voor mediageschiedenis 7 (2004) 2, pp. 118-125.

Fine, Gary Alan (2002): Shared Fantasy. Role-Playing Games as Social Worlds. Chicago: University of Chicago Press.

Jansz, Jeroen; Raynel G. Martis (2003): The Representation of Gender and Ethnicity in Digital Interactive Games. In: Marinka Copier, Joost Raessens, eds.: Level Up. Digital Games Research Conference. Utrecht: Digra, pp. 260-269.

Meder, Theo (2008): Internet. In: Donald Haase, ed.: The Greenwood Encyclopedia of Folktales \& Fairy Tales. Westport, London: Greenwood Press, vol. 2, pp. 489-495.

Mostow, Jonathan, director (2009): Surrogates. Touchstone Pictures.

Murray, Janet H. (1998): Hamlet on the Holodeck. The Future of Narrative in Cyberspace. Fourth impression. Cambridge MA: MIT Press.

Pearce, Celia (2002): Story as play space: narrative in games. In: L. King, ed.: Game on: The History and Culture of Video Games. London, Laurence King Publishing, pp. 112-119.

Pfeijffer, Ilja Leonard (2007): Second Life. Verhalen en reportages uit een tweede leven. Amsterdam: Uitgeverij De Arbeiderspers.

Tavinor, Grant (2009): The Art of Videogames. Malden, Oxford: Wiley-Blackwell. 
Timroff, Bob (2007): ThatSLife! Een praktische gids voor Second Life. [S.1.]. Van Duuren Media.

Trippe, Rebecca (2009): Virtuelle Gemeinschaften in Online-Rollenspielen. Eine empirische Untersuchung der sozialen Strukturen in MMORPGs. Münster, LIT Verlag.

Veugen, Connie (2004): Here be dragons. Voorgeschiedenis en ontstaan van adventure games. Tijdschrift voor mediageschiedenis 7 (2004) 2, pp. 77-99.

Walter, Klaus (2002): Grenzen spielerischen Erzählens: Spiel- und Erzählstrukturen in graphischen Adventure Games. Siegen: Universitätsverlag Siegen. 